\title{
KOMIK BENCANA MENINGKATKAN SIKAP KESIAPSIAGAAN \\ BENCANA PADA ANAK SEKOLAH DASAR NEGERI BULAKAN KECAMATAN GUNUNG KENCANA BANTEN SELATAN TAHUN 2017
}

\author{
Siti Wasliyah ${ }^{1}$ \\ ${ }^{1}$ Jurusan Keperawatan Poltekkes Kemenkes Banten
}

\begin{abstract}
ABSTRAK
Indonesia merupakan salah satu daerah bencana paling aktif di dunia karena posisi geografisnya. Elemen-elemen dalam kesiapan bencana meliputi pengetahuan personal, komunitas dan tingkat nasional. Elemen lain yang tidak kalah penting antara lain pendidikan bencana, dampak respon bencana dan pengembangan respon lokal seperti sistem peringatan dini (early warning system) sebagai bagian penting kesiapan bencana. (Clust,Human \& Simpson, 2007). Pengembangan strategi komunikasi yang efektif dibutuhkan untuk mendukung program mandiri terutama untuk anak sekolah, yang merupakan kelompok rentan bencana. Komik adalah salah satu media pembelajaran menarik perhatian karena pesan dapat disampaikan melalui gambar dan kata-kata (Cedri S, et all, 2015). Penelitian ini adalah penelitian kuasi eksperimen dengan pendekatan pretest and postets group design, bertujuan untuk mengidentifikasi pengaruh penggunaan komik bencana dalam meningkatkan sikap kesiapsiagaan bencana pada anak sekolah dasar. Penelitian dilakukan di Sekolah Dasar Bulakan di Kecamatan Gunung Kencana Banten Selatan pada bulan Juni - Nopember 2017 dengan populasi siswa SDN Bulakan. Metode sampling yang digunakan adalah consecutive sampling berjumlah 50 orang untuk masing-masing kelompok intervensi dan kontrol. Rerata sikap pada kelompok yang tidak membaca komik (kontrol) adalah 33,82 dengan standar deviasi 3,72. Pada kelompok yang diberikan intervensi membaca komik didapat rata-rata sikap adalah 34,82 dengan standar deviasi 3,61. Hasil uji statsitik diadapatkan nilai $P$ value 0,044 ( $P$ value $<0,05)$ maka dapat disimpulkan ada perbedaan yang signifikan antara rata-rata sikap kelompok intervensi dan kelompok kontrol. Peningkatan sikap kesiapsiagaan bencana pada anak sekolah dasar khususnya dapat dilakukan dengan pemberian komik bencana, baik di sekolah sebagai tambahan media pembelajaran maupun sebagai wahana baca di rumah.
\end{abstract}

Kata Kunci: komik bencana, kesiapsiagaan bencana, sekolah dasar

Korespondensi: Kusniawati. E-mail: els.siti@gmail.com

\section{PENDAHULUAN}

Indonesia merupakan salah satu daerah bencana paling aktif di dunia karena posisi geografisnya.

Data dari Badan Penanggulangan Bencana
Nasional (BNPB), dalam kurun waktu 30 tahun terakhir (1982-2014) terjadi 13.729 kejadian bencana, yang didominasi oleh banjir dan diikuti oleh tanah longsor, angin kencang, kekeringan 
dan bencana lain. Bencana yang paling banyak korban adalah bencana gempa bumi yang diikuti oleh tsunami (174.101 orang meninggal), gempa bumi (15.250 orang meninggal), banjir dan tanah longsor ( 7.555 orang meninggal dan bencana lain (28.603 jiwa).(Kemendikbud, 2015). BNPB mencatat pada bulan Januari sampai Maret tahun 2017 telah terjadi 883 bencana di seluruh Indonesia. Banten merupakan daerah rawan bencana, dimana lebih dari 10 jenis bencana, rawan terjadi didaerah banten dan sekitarnya Pada penilaian indeks risiko bencana daerah dua wilayah di Banten yang memiliki skor di atas 150 poin adalah Kabupaten Lebak dan Pandeglang.(BNPB, 2017).

Pemerintah Indonesia menetapkan UndangUndang No.24 Tahun 2007 tentang Penanggulangan Bencana yang menekankan bahwa penanggulangan bencana tidak hanya terpaku pada tahap tanggap darurat/respons saja tetapi juga mencakup tahap pra bencana (kesiapsiagaan) dan pasca bencana (pemulihan). Elemen-elemen dalam kesiapan bencana meliputi pengetahuan personal, komunitas dan tingkat nasional. Elemen lain yang tidak kalah penting antara lain pendidikan bencana, dampak respon bencana dan pengembangan respon lokal seperti sistem peringatan dini (early warning system) sebagai bagian penting kesiapan bencana. (Clust,Human \& Simpson, 2007). Beberapa penelitian membuktikan bahwa intervensi berbasis sekolah meningkatkan pengetahuan bencana teoritis yang mungkin juga mencakup keterampilan praktis; Namun, belum tentu merubah perilaku bencana. Hasil terbaik akan diperoleh dengan menggabungkan kegiatan teoritis dan praktis di sekolah, keluarga, masyarakat, dan program pendidikan mandiri. Kebutuhan mendesak untuk dorongan pendidikan terpadu untuk mencapai perubahan perilaku adaptif terhadap kesiapsiagaan bencana sangat dibutuhkan untuk meningkatkan peluang bertahan hidup bagi korban bencana. (Codeanu TA, Celenza TA, Jacobs, 2014).

Pengembangan strategi komunikasi yang efektif dibutuhkan untuk mendukung program mandiri terutama untuk anak sekolah, dimana pemerintah telah mencanangkan programnya melalui program sekolah siaga bencana. Kelompok anak sekolah termasuk dalam kelompok rentan bencana dan merupakan kelompok pemahaman dasar untuk mencegah terjadinya efek bencana lebih lanjut, sehingga dibutuhkan strategi yang efektif untuk menyampaikan pesan yang bisa tetap mereka pahami di lingkungan rumah. Sebuah studi mengenai pencegahan luka bakar di Italia terhadap 370 anak sekolah mendapatkan hasil adanya peningkatan pengetahuan yang signifikan setelah diberikan paket pencegahan luka bakar yang salah satu diantaranya adalah komik. Komik dapat menarik perhatian karena pesan dapat disampaikan melalui gambar dan kata-kata. (Cedri S, et.all, 2015).

Komik adalah bentuk seni gambar yang popular terutama di kalangan anak-anak, dengan demikian dapat dimanfaatkan sebagai media yang potensial untuk pendidikan (Tatalovic,2009). Pada usia 11-12 tahun perkembangan siswa SD seharusnya memerlukan media yang berwujud konkret (Aprianto Richi L, Ningsih Sukri D, 2016). Media pembelajaran yang dapat digunakan siswa baik di sekolah maupun di 
rumah adalah komik, sehinggan perlu diadakan studi lebih lanjut apakah komik dapat meningkatkan sikap kesiapsiagaan bencana pada anak sekolah dasar.

\section{METODOLOGI PENELITIAN}

Desain penelitian menggunakan quasi experiment dengan pendekatan Pretest-Posttest Control Group Design. Pada penelitian ini terdapat dua kelompok, yaitu kelompok intervensi dan kelompok kontrol.

Semua responden dari dua kelompok diberikan kuesioner sebelum dilakukan intervensi. Setelah mengisi kuesioner pre test, kelompok intervensi diberikan aktivitas membaca komik selama lebih kurang 1 jam, kemudian diadakan pengukuran post test pada kedua kelompok. Penelitian ini dilakukan pada siswa sekolah dasar (SD) Negeri Bulakan di Gunung Kencana Banten Selatan dengan kriteria minimal siswa kelas $4 \mathrm{SD}$, pada bulan September 2017. Analisis data dilakukan secara univariat dan bivariate. Analisis univariate digunakan untuk mengetahui usia, jenis kelamin dan pengetahuan, sedangkan analisis bivariate menggunakan uji t-test untuk mengetahui apakah ada pengaruh pemberian komik bencana terhadap sikap kesiapsiagaan bencana

\section{HASIL PENELITIAN}

\section{Analisis Univariat}

Analisis univariat dilakukan untuk menggambarkan karakteristik responden yang meliputi usia dan jenis kelamin dan pengetahuan. Hasil analisis univariat dijelaskan dalam tabel sebagai berikut :
Tabel 1. Distribusi Frekuensi Responden berdasarkan usia di SD Negeri Bulaka Gunung Kencana Banten Selatan Tahun 2017 (N=100)

\begin{tabular}{lccccl}
\hline Variabel & Mean & Median & SD & $\begin{array}{l}\text { Min- } \\
\text { Maks }\end{array}$ & $\begin{array}{l}\text { P Value } \\
\text { Usia }\end{array}$ \\
& & & & & \\
$\begin{array}{l}\text { Kel. } \\
\text { Intrvensi }\end{array}$ & 10,96 & 11 & 0,85 & $10-13$ & 0,009 \\
$\begin{array}{l}\text { Kel } \\
\text { Kontrol }\end{array}$ & 10,52 & 10 & 0,78 & $10-13$ & \\
\hline
\end{tabular}

Tabel 1 menunjukkan bahwa didapatkan rata-rata umur responden pada kelompok intervensi adalah 10,96 dengan standar deviasi 0,85 dan rata-rata kelompok kontrol adalah 10,52 dengan standar deviasi 0,78.Umur termuda adalah 10 dan tertua adalah 13 baik pada kelompok intervensi maupun kelompok kontrol. Pada variabel usia telah dilakukan uji $\mathrm{T}$ independent untuk melihat perbedaan usia antara 2 kelompok. Hasil analisis didapatkan nilai $p$ value $=0,009$ (p value < $0,005)$ sehingga dapat disimpulkan tidak ada perbedaan yang bermakna pada usia antara kelompok intervensi dan kelompok kontrol.

Tabel 2. Distribusi Frekuensi Responden berdasarkan Jenis Kelamin di SD Negeri Bulakan Gunung Kencana Banten Selatan Tahun $2017(\mathrm{~N}=100)$ 


\begin{tabular}{lcccc}
\hline $\begin{array}{c}\text { Varia- } \\
\text { bel }\end{array}$ & $\begin{array}{c}\text { Peremp } \\
\text { uan }\end{array}$ & $\begin{array}{c}\text { Laki- } \\
\text { laki }\end{array}$ & Juml. & $\begin{array}{c}\text { P } \\
\text { Value }\end{array}$ \\
\hline $\begin{array}{l}\text { Jenis } \\
\text { Kelamin }\end{array}$ & & & & \\
$\begin{array}{l}\text { Kel } \\
\text { intrvensi }\end{array}$ & $19(38 \%)$ & $31(62 \%)$ & $\begin{array}{c}50 \\
(100 \%)\end{array}$ & 0,840 \\
Kel & $20(40 \%)$ & $30(60 \%)$ & & \\
Kontrol & & & $\begin{array}{c}50 \\
(100 \%)\end{array}$ & \\
& & & $\begin{array}{c}100 \\
(100 \%)\end{array}$ & \\
\hline & $39(39 \%)$ & $61(61 \%)$ & &
\end{tabular}

Tabel 2 menunjukkan distribusi frekuensi responden berdasarkan karakteritik jenis kelamin yaitu pada kelompok intervensi berjenis kelamin perempuan sebanyak 19 orang (38\%) dan laki-laki 31 orang (62\%). Pada kelompok kontrol responden berjenis kelamin perempuan sebanyak 20 orang (40\%) dan laki-laki 30 orang (60\%). Jumlah keseluruhan responden berjenis kelamin perempuan sebanyak 39 orang (39\%) dan laki-laki 61 orang (61\%). Pada analisis bivariate didapatkan nilai $p$ value $=0,840$, sehingga dapat disimpulkan tidak ada perbedaan jenis kelamin yang bermakna antar kelompok intervensi dan kelompok kontrol.

Tabel 3. Distribusi Frekuensi Responden berdasarkan Pengetahuan di SD Negeri Bulakan Gunung Kencana Banten Selatan Tahun 2017

$$
(\mathrm{N}=100)
$$

Tabel 3 menunjukkan distribusi frekuensi responden berdasarkan karakteritik pengetahuan yaitu pada kelompok intervensi, responden yang belum tahu tentang bencana sebanyak 16 orang (32\%) dan yang sudah tahu tentang bencana berjumlah 34 orang (68\%). Pada kelompok kontrol responden yang belum tahu sebanyak 39 orang $(78 \%)$ dan yang sudah tahu tentang bencana 11 orang (22\%). Jumlah keseluruhan responden yang belum tahu tentang bencana adalah 55 orang (55\%) lebih banyak dari pada yang sudah tahu yaitu 45 orang (45\%). Pada hasil analisis bivariate ditemukan nilai $\mathrm{p}$ value $=0,000$ yang berarti bahwa terdapat perbedaan pengetahuan yang bemakna antara kelompok intervensi dan kelompok kontrol.

Tabel 4. Distribusi Frekuensi Responden Berdasarkan sikap kesiapsiagaan bencana sebelum intervensi di SD Negeri Bulakan Gunung Kencana Banten Selatan Tahun $2017(\mathrm{~N}=100)$

\begin{tabular}{|c|c|c|c|c|c|c|}
\hline \multirow{2}{*}{$\begin{array}{l}\text { Variabel } \\
\text { Sikap } \\
\text { Kesiap- } \\
\text { siagaan } \\
\text { bencana }\end{array}$} & \multicolumn{2}{|c|}{$\begin{array}{l}\text { Sikap } \\
\text { Negatif }\end{array}$} & \multicolumn{2}{|c|}{$\begin{array}{l}\text { Sikap } \\
\text { Positif }\end{array}$} & \multicolumn{2}{|c|}{ Jumlah } \\
\hline & $\mathbf{N}$ & $\%$ & $\mathbf{N}$ & $\%$ & $\mathbf{N}$ & $\%$ \\
\hline $\begin{array}{l}\text { Kel. } \\
\text { Intrvensi }\end{array}$ & 19 & $38 \%$ & 31 & $\begin{array}{l}62 \\
\%\end{array}$ & 50 & $100 \%$ \\
\hline $\begin{array}{l}\text { Kel. } \\
\text { Kontrol }\end{array}$ & 21 & $42 \%$ & 29 & $\begin{array}{l}58 \\
\%\end{array}$ & 50 & $100 \%$ \\
\hline Jumlah & 40 & $40 \%$ & 60 & $\begin{array}{l}60 \\
\%\end{array}$ & 100 & $100 \%$ \\
\hline
\end{tabular}

Kel.

$\begin{array}{llllll}16 & 32 \% & 34 & 68 & 50 & 100 \%\end{array}$

Intrvensi

$\begin{array}{lllllll}\text { Kel. } & 39 & 78 \% & 11 & 22 & 50 & 100 \%\end{array}$

Tabel 4. menunjukkan distribusi frekuensi Kontrol responden berdasarkan karakteritik sikap \begin{tabular}{lllllllll}
\hline Jumlah & 55 & $55 \%$ & 45 & 45 & 100 & $100 \%$ & kesiapsiagaan bencana sebelum intervensi yaitu
\end{tabular} pada kelompok intervensi, responden dengan 
sikap negatif sebanyak 19 orang (38\%) dan sikap positif 31 orang (62\%). Pada kelompok control, responden dengan sikap negative lebih sedikit yaitu 21 orang (42\%) disbanding sikap positif yaitu 29 orang (58\%). Responden dengan sikap positif baik pada kelompok intervensi maupun kelompok control lebih banyak yaitu sebanyak 31 orang $(62 \%)$ pada kelompok intervensi dan pada kelompok kontrol sebanyak 29 orang (58\%). Jumlah keseluruhan responden yang memiliki sikap positif sebelum dilakukan intervensi adalah 60 orang.

Tabel 5. Distribusi Frekuensi Responden

Berdasarkan sikap kesiapsiagaan bencana sesudah intervensi di SD Negeri Bulakan Gunung Kencana Banten Selatan Tahun 2017

$$
(\mathrm{N}=100)
$$

\begin{tabular}{lcccccc}
\hline $\begin{array}{l}\text { Variabel } \\
\begin{array}{l}\text { Sikap } \\
\text { Kesiap- } \\
\text { siagaan } \\
\text { bencana }\end{array}\end{array}$ & $\begin{array}{c}\text { Sikap } \\
\text { Negatif }\end{array}$ & $\begin{array}{c}\text { Sikap } \\
\text { Positif }\end{array}$ & Jumlah \\
\cline { 2 - 7 } & $\mathbf{N}$ & $\%$ & $\mathbf{N}$ & $\%$ & $\mathbf{N}$ & $\%$ \\
\hline Kel. & 16 & $32 \%$ & 34 & 68 & 50 & $100 \%$ \\
Intrvensi & & & & $\%$ & & \\
Kel. & 26 & $52 \%$ & 24 & 48 & 50 & $100 \%$ \\
Kontrol & & & & $\%$ & & \\
\hline Jumlah & 42 & $42 \%$ & 58 & 58 & 100 & $100 \%$ \\
& & & & $\%$ & &
\end{tabular}

Tabel 5 menunjukkan distribusi frekuensi responden berdasarkan karakteritik sikap kesiapsiagaan bencana setelah intervensi yaitu pada kelompok intervensi, responden dengan sikap negatif sebanyak 16 orang (32\%) dan sikap positif 34 orang (68\%). Pada kelompok kontrol responden dengan sikap negative sebanyak 26 orang $(52 \%)$ dan sikap positif 24 orang (48\%). Jumlah responden yang memiliki sikap positif pada pengukuran kedua atau setelah intervensi lebih banyak dari pada sikap negative yaitu adalah 58 orang (58\%).

Tabel 6. Distribusi rata-rata Sikap Kesiapsiagaan Bencana Sebelum dan Sesudah Membaca Komik Bencana Pada Kelompok Intervensi

\begin{tabular}{lccclc}
\hline Variabel & Mean & $\begin{array}{l}\text { Standar } \\
\text { Deviasi } \\
\text { (SD) }\end{array}$ & SE & $\begin{array}{l}\text { P } \\
\text { Value }\end{array}$ & N \\
\hline $\begin{array}{l}\text { Sikap Pre } \\
\text { Intrvensi }\end{array}$ & 34,70 & 3,91 & 0,55 & 0,870 & 50 \\
$\begin{array}{l}\text { Sikap } \\
\text { Post }\end{array}$ & 34,82 & 3,61 & 0,51 & & 50 \\
Kontrol & & & & & \\
\end{tabular}

Tabel 6 menunjukkan rata-rata sikap sebelum diberikan intervensi adalah 34,70 dengan standar deviasi 3,91. Pada Pengukuran kedua didapat rata-rata sikap setelah diberikan intervensi adalah 34,82 dengan standar deviasi 3,61. Terlihat nilai mean perbedaan antara pengukuran pertama dan kedua adalah 0,12 dengan standar deviasi 0,3 Hasil uji statsitik diadapatkan nilai 0,870 maka dapat disimpulkan tidak ada perbedaan yang signifikan antara pengkuran sikap sebelum dan setelah dilaksanakan intervensi membaca komik.

Tabel 7. Distribusi rata-rata Sikap Kesiapsiagaan

Bencana dengan Dua Kali Pengukuran Pada Kelompok Kontrol

\begin{tabular}{lccccc}
\hline Variabel & Mean & $\begin{array}{l}\text { Standar } \\
\text { Deviasi } \\
\text { (SD) }\end{array}$ & SE & $\begin{array}{l}\text { P } \\
\text { Value }\end{array}$ & N \\
\hline $\begin{array}{l}\text { Sikap Pre } \\
\text { Intrvensi }\end{array}$ & 34,70 & 3,91 & 0,55 & 0,073 & 50 \\
Sikap & & & & & \\
$\begin{array}{l}\text { Post } \\
\text { Kontrol }\end{array}$ & 33,32 & 3,72 & 0,52 & & 50 \\
\hline
\end{tabular}


Tabel 7 menunjukkan rata-rata sikap pada pengukuran pertama adalah 34,70 dengan standar deviasi 3,91. Pada pengukuran kedua didapat rata-rata sikap setelah diberikan intervensi adalah 33,32 dengan standar deviasi 3,71. Terlihat nilai mean perbedaan antara pengukuran pertama dan kedua ternyata menurun adalah 1,38 dengan standar deviasi 0,19 . Hasil uji statsitik diadapatkan nilai 0,073 maka dapat disimpulkan tidak ada perbedaan yang signifikan antara pengkuran pertama dan kedua pada kelompok kontrol.

Tabel 8. Perbedaan rata-rata Sikap Kesiapsiagaan Bencana Setelah Membaca Komik Antara Kelompok Intervensi dan Kontrol

\section{PEMBAHASAN}

Hasil penelitian apabila dilihat dari analisis univariat tampak bahwa terdapat perbedaan yang positif setelah dilakukan intervensi membaca komik. Komik Bencana merupakan salah satu media pembelajaran untuk meningkatkan pemahaman siswa sekolah dasar mengenai pendidikan bencana. Selain menarik untuk dibaca, komik bencana merupakan sarana yang mengasyikkan bagi siswa untuk mempelajari tanggap bencana dan mengembangkan minat baca siswa. Pembuatan komik bencana bertujuan untuk menjelaskan cara meningkatkan pemahaman siswa sekolah dasar terhadap materi pendidikan tanggap bencana. Pemakaian media dalam proses pembeljaaran dapat mebangkitkan keinginan dan minat yang baru, membangkitkan

\begin{tabular}{lccclc}
\hline Variabel & Mean & $\begin{array}{l}\text { Standar } \\
\text { Deviasi } \\
\text { (SD) }\end{array}$ & SE & $\begin{array}{l}\text { P } \\
\text { Value }\end{array}$ & $\mathbf{N}$ \\
\hline $\begin{array}{l}\text { Tidak } \\
\text { Baca }\end{array}$ & 33,32 & 3,72 & 0,52 & 0,044 & 50 \\
Komik & & & & & \\
Baca & 34,82 & 3,61 & 0,51 & & 50 \\
Komik & & & & & \\
\hline
\end{tabular}

Tabel 8 menunjukkan rata-rata sikap pada kelompok yang tidak membaca komik (kontrol) adalah 33,82 dengan standar deviasi 3,72. Pada kelompok yang diberikan intervensi membaca komik didapat rata-rata sikap adalah 34,82 dengan standar deviasi 3,61. Hasil uji statsitik diadapatkan nilai $P$ value 0,044 ( $P$ value < 0,05)maka dapat disimpulkan ada perbedaan yang signifikan antara rata-rata sikap kelompok intervensi dan kelompok kontrol. motivasi, dan memberikan rangsangan kegiatan belajar, bahkan pengaruh-pengaruh psikologis pada anak. Media akan dapat menarik perhatian minat anak dan akhirnya berkonsentrasi untuk belajar dan memahami pelajaran (Hamalik dalam Arsyad, 2006, dalam sessiani 2007)

Pada analisis bivariat dilakukan dengan menggunakan uji $\mathrm{T}$ dependent setelah dilakukan uji normalitas, untuk mengetahui perbedaan rerata pada responden dengan kelompok yang sama. Tabel 5.6 menunjukkan rata-rata sikap sebelum diberikan intervensi adalah 34,70 dengan standar deviasi 3,91. Pada Pengukuran kedua didapat rata-rata sikap setelah diberikan intervensi adalah 34,82 dengan standar deviasi 3,61 . Terlihat nilai mean perbedaan antara pengukuran pertama dan kedua adalah 0,12 dengan standar deviasi 0,3. Hasil uji statsitik diadapatkan nilai 0,870 maka dapat disimpulkan 
tidak ada perbedaan yang signifikan antara pengkuran sikap sebelum dan setelah dilaksanakan intervensi membaca komik pada kelompok intervensi.

Tabel 5.7 menunjukkan rata-rata sikap pada pengukuran pertama adalah 34,70 dengan standar deviasi 3,91. Pada Pengukuran kedua didapat rata-rata sikap setelah diberikan intervensi adalah 33,32 dengan standar deviasi 3,71. Terlihat nilai mean perbedaan antara pengukuran pertama dan kedua ternyata menurun adalah 1,38 dengan standar deviasi 0,19. Hasil uji statsitik diadapatkan nilai 0,073 maka dapat disimpulkan tidak ada perbedaan yang signifikan antara pengkuran pertama dan kedua pada kelompok kontrol.

Pada kelompok intervensi didapatkan perbedaan rerata pada pengkuran sebelum dan setelah intervensi. Peningkatan rata-rata nilai sikap bisa terkait dengan pengetahuan yang telah diperoleh responden setelah membaca komik bencana. Hal ini berbeda dengan kelompok kontrol dimana rata-rata nilai sikap menurun 0,19. Kelompok kontrol hanya diberikan kuesioner sikap tanpa diberikan pengetahuan tambahan dengan intervensi membaca komik. Hal ini sesuai dengan penelitian I'liyin yeyen Janatul (2016) tentang penggunaan media komik untuk pembelajaran kebencanaan longsor di SMPN 41 Semarang, yang mendapatkan hasil setelah dilakukan pembelajaran pada kelas eksperimen dengan mengunakan media komik bencana longsor didapatkan rata-rata hasil posttest mencapai 82,2 sedangakan pada kelas control, rata-rata hasil posttest mencapai 68,3. Aktifitas afektif pada pembelajaran kebencanaan menggunakan media komik mempunyai nilai kriteria sangat baik dan aktifitas psikomotorik mempunyai kriteria baik.

Pengaruh komik bencana terhadap sikap kesiapsiagaan bencana diukur dengan membandingkan nilai rata-rata pada kelompok intervensi dan kelompok kontrol dengan melakukan analisis uji $\mathrm{t}$ independent. Tabel 5.8 menunjukkan rata-rata sikap pada kelompok yang tidak membaca komik (kontrol) adalah 33,82 dengan standar deviasi 3,72. Pada kelompok yang diberikan intervensi membaca komik didapat rata-rata sikap adalah 34,82 dengan standar deviasi 3,61. Hasil uji statsitik diadapatkan nilai $P$ value 0,044 ( $P$ value < 0,05)maka dapat disimpulkan ada perbedaan yang signifikan antara rata-rata sikap kelompok intervensi dan kelompok kontrol.

Komik adalah gambar yang berjajar dalam urutan yang disengaja, dimaksudkan untuk menyampaikan informasi atau menghasilkan respon estetik pembaca. Komik juga dapat diajdikan media pembelajaran. (McClud, 1993 dalam Gumelar, 2011). Pendidikan tanggap bencana untuk anak-anak seharusnya mempunyai media yang berbeda dengan orang dewasa dalam menyampaikannya. Namun selama ini pendidikan tanggap bencana masih dijadikan satu bab dan dimasukkan pada salah satu mata pelajaran di sekolah. Cara ini terkesan membosankan bagi anak-anak karena tidak semua anak-anak suka membaca apalagi membaca buku sekolah (www.elib.unikom.ac.id). Melalui media gambar pesan dapat dituangkan melalui simbol-simbol komunikasi visual media 
gambar diharapkan dapat menggairahkan dan memberikan motivasi kepada siswa untuk ikut berpertisipasi secara aktif dan berinteraksi dalam proses pembelajaran (Suyuthi,2011).

Komik adalah salah satu jenis media yang dapat digunakan untuk pembelajaran, dan komik edukasi sudah digunakan dalam edukasi bencana baik melalui materi edukasi terbitan lembaga pemerintah maupun pihak lembaga mitigasi bencana. Komik edukasi dapat menyampaikan materi pembelajaran dengan menarik, sehingga cocok digunakan untuk media pembelajaran (Sutrisna CE dan Mansoor AZ, 2017). Menurut Suyuthi, 2011, penggunaan efek visual terutama komik pada pendidikan tanggap bencana untu anak-anak bertujuan untuk menambah minat anak-anak dalam mempelajari cara mencegah atau mengahadapi bencana. Hasil penelitian yang dilakukan oleh colletti dan sekartawi tahun 1995, menunjukkan bahwa penggunaan media pengajaran visual lebih efektid dibandigkan penggunaan model pengajaran lainnya. Gambar atau komik berperan sebagai media pengajaran untuk mempermudah anak-anak dalam mempelajari teknik-teknik mengahadapi bencana, sehingga belajar tanggap bencana terkesan lebih menarik dan menyenangkan (Suyuthi, 2011).

Penelitian Sinha, et all tahun 2015 tentang buku komik dapat mendidik anak-anak tentang keselamatan luka bakar di Negara-negara berkembang mendapaykan hasil bahwa terdapat peningkatan yang signifikan pengetahuan yang signifikan pada kelompok yang diberikan intervensi $\quad(\mathrm{P}<0.1) . \quad$ Pelajaran tersebut membutuhkan total waktu 30 menit per kelas.
Para guru melaporkan bahwa siswa senang membaca komik dan terlibat selama sesi berlangsung. Studi ini juga menunjukkan bahwa sebuah komik memiliki nilai dalam mengajarkan anak-anak tentang kesadaran terbakar. Buku komik merupakan metode hemat biaya sebagai media pembelajaran bagi anak-anak.

Studi mengenai pemanfaatan sastra anak sebagai mitigasi bencana mengemukakan bahwa komik lebih tepat diberikan pada anak usia 11 tahun sampai remaja. Upaya mitigasi terhadap masalah bencana dapat dilakukan dengan memahami isi teks, memberikan tanggapan terhadap masalah bencana dan penanggulangan serta pencegahannya atau menuliskan fenomena bencana alam dan sosial di masyarakat berdasarkan teks yang dibaca.(Liliani Else, 2015)

\section{SARAN}

Peningkatan sikap kesiapsiagaan bencana pada anak sekolah dasar khususnya dapat dilakukan dengan pemberian komik bencana, baik di sekolah sebagai tambahan media pembelajaran maupun sebagai wahana baca di rumah. Bagi peneliti selanjutnya perlu melakukan penelitian lanjutan dengan peningkatan media lainnya untuk meningkatkan sikap kesiapsiagaan bencana, serta dapat mencari efektivitas media tersebut.

\section{DAFTAR PUSTAKA}

Anonima, 2016, Pengaruh Pengetahuan, Sikap dan Kesiapsiagaan Rumah Tangga Dalam Menghadapi Bencana Gempa Bumi Di Desa Deyah Raya Kecamatan Syiah Kuala Kota Banda Aceh diakses dari http://repository.usu.ac.id/bidstream/ha 
ndle tanggal 12 April 2017

Aprianto Richi Ledi, Ningsih Sukri Dwi, 2016, Pengaruh Media Pembelajaran Komik Terhadap Hasil Belajar IPS Materi Bencana Alam Siswa Kelas VI Sekolah Dasar, Jurnal Penelitian Pendidikan, Vol.8 Nomor 1, Juni 2016, hlm1189-1249. Jakarta

BNPB, 2008, Peraturan Kepala Badan Nasional Penanggulangan Bencana No.4 Tahun 2008 Tentang Pedoman Penyusunan Rencana Penanggulangan Bencana, diakses dari https://BNPB.go.id>migration>pubs tanggal 11 April 2017

Clust, Michael, RJ. Human, dan DM. Simpson. 2007.Mapping and rail safety: the Development of Mapping Display Technology for Data Communication. Center for Hazards Research and Policy Development.

Connor SB, 2014, Factors Associated with the Intention of Health Care Personnel to Respond to a Disaster. Diakses dari http://www.ncbi.nlm.nih.gov/pubmed/2 5384396 tanggal 28 Maret 2017.

Cedri S et all, 2015, Development of an Effective Communication Strategy for the Prevention of Burns in Children: the Prius Project, diakses dari https://www.ncbi.nlm.nih.gov/pubmed/ ?term=DISASTER+COMIC tanggal 10 April 2017

Codeanu TA, Celenza A, Jacobs, 2014 ,Does disaster education of teenagers translate into better survival knowledge, knowledge of skills, and adaptive behavioral change? A systematic literature review..Prehosp Disaster Med. 2014 Dec;29(6):629-42. doi: $\quad 10.1017 / \mathrm{S} 1049023 X 14001083$. Epub 2014 Oct 20 diakses dari https://www.ncbi.nlm.nih.gov/pubmed/
, tanggal 10 April 2017

Djafar M I, Mantu F N, Patellongi I J. 2013. Pengaruh Tentang Kesiapsiagaan Bencana Banjir Terhadap Pengetahuan dan Sikap Kepala Keluarga di Desa Romang Tangaya Kelurahan Tamangapa Kecamata Manggala Kota Makassar. Laporan Penelitian. Makassar.

Duong, Karen,2009, Disaster Education and training on emergency nurses in South Australia. Australian Emergency Nursing Journal. Australia.

Gumelar, MS, 2011, Comic Making, Jakarta: Indeks

Husna Cut, 2012, Faktor-faktor yang Mempengaruhi Kesiapsiagaan Bencana di RSUDZA Banda Aceh, Idea Noursing Journal, (ISSN: 20872879), diakses dari http://jurnal.unsyiah.ac.id/INJ/article/v iewFile/1578/1459, tanggal 14 Oktober 2017

I'liyin Yayan Janatul, 2016, Penggunaan Media Komik Untuk Pembelajaran Kebencanaan Longsir di SMPN 41 Semarang, Skripsi, Universitas Negeri Semarang, diakses dari http://lib.unnes.ac.id/27382/1/3201412 147.pdf, tanggal 14 Oktober 2017

Liliani Else, 2015, Pemanfaatan Sastra Anak Sebagai Media Mitigasi Bencana, diakses dari http://staffnew.uny.ac.id/upload/13229 9491/penelitian/ABSTRAK+ PEMANFAATAN+SASTRA+ANAK +SEBAGAI+MEDIA+MITIGASI+BE NCANA.pdf, tanggal 10 April 2017

Sinha,et all, 2011, Comic Books can Educate Children about Burn Safety in Developing Countries, diakses dari 
https://www.ncbi.nlm.gov>pubmed tanggal 12 April 2017

Sutrisna Caesar Esaputra, Mansoor Alavanov Zpalanzani, 2017, Perancangan Komik Edukasi Bencana Gempa Bumi Untuk Murid SD Umur 9-12 Tahun di Indonesia, Jurnal Tingkat Sarjana Seni Rupa dan Desain No.1, diaskes dari urnal-

s1.fsrd.itb.ac.id/index.php/viscom/artic le/download/592/508 tanggal 14 Oktober 2017.

Tatalovic, M, 2009, Science Comic As Tools for Science Education and Communication, A Brief, Explanatory Study. JCOM Journal of Science Communication Volume 08(04):1-17.

Wikipedia, 2017, Komik, diakses dari https://id.m.wikipedia.org/komik, tanggal 11 April 2017 